\title{
Antibody Unit
}

National Cancer Institute

\section{Source}

National Cancer Institute. Antibody Unit. NCI Thesaurus. Code C111129.

A unit of antibody concentration measured by comparison ag ainst a known concentration of antibodies in a standard reference specimen. 